\title{
Impact of an Awareness Campaign for the Detection of Axial Spondyloarthritis in Patients with Inflammatory Back Pain
}

\author{
Emilce Edith Schneeberger ${ }^{1}$, Gustavo Citera ${ }^{1 *}$, Emilio Buschiazzo $^{2}$, Alejandro \\ Cayetti $^{1}$, Natalia Zamora ${ }^{1}$, Fernando Andrés Sommefleck ${ }^{1}$, María Celeste Orozco ${ }^{1}$, \\ Maria Elena Crespo Espindola ${ }^{2}$ \\ ${ }^{1}$ Section of Rheumatology. Instituto de Rehabilitación Psicofísica, Buenos Aires, Argentina. \\ ${ }^{2}$ Section of Rheumatology, Hospital Señor del Milagro, Salta, Argentina.
}

Received: November 08, 2016; Accepted: January 21, 2017; Published: February 2, 2017

*Corresponding author: Gustavo Citera MD, Chief Section of Rheumatology, Instituto de Rehabilitación Psicofísica. Echeverría 955 (zipcode 1428), Buenos Aires, Argentina. Tel: 541147888841; Fax: 541147885552; E-mail: gustavocitera@gmail.com

\begin{abstract}
The objectives of the study are to identify patients with Inflammatory Back Pain (IBP) through an awareness campaign to the general population and to assess the impact of different advertising media.

Methods: A four-week awareness campaign was presented through various communication media venues, raising awareness about AxSpA, and encouraging patients with IBP to contact us via e-mail or telephone call. If they met the inclusion criteria they were given an appointment. If the patient did not meet the diagnostic criteria at the first appointment, HLA-B27 and magnetic resonance imaging were performed.

Results: A total of 900 patients replied ( 449 by telephone and 451 by e-mail). After excluding ineffective calls and emails, 587 patients were included (226from phone calls and 361 from e-mails); $61.5 \%$ of this patients replied after seen a TV advertisement. Following the initial questionnaire, $70 \%$ of the patients from the call center and $7.3 \%$ via email met the inclusion criteria. 157 appointments were given, and only $80(50.9 \%)$ attended. After clinical evaluation, 42 of the 80 patients $(52.5 \%)$ definitively met the inclusion criteria. After clinical evaluations, 9 patients were classified as AxSpa. When we compared those with and without an AxSpA diagnosis, axial morning stiffness and higher enthesis score were significantly more frequent in the AxSpA group.
\end{abstract}

Conclusion: The frequency of AxSpA in patients with IBP in our population was similar to that reported in literature. Television was clearly the best venue of communication, and the call center was the most effective way to contact potential patients.

Keywords: Axial Spondyloarthritis; Low Back Pain; Awareness; Early detection; Ankylosing Spondylitis

\section{Introduction}

Axial Spondyloarthritis (AxSpA) is a chronic inflammatory disease, which primarily affects the spine. It is strongly associated with the major histocompatibility complex (MHC) class I allele HLA-B27, particularly in those who develop Ankylosing Spondylitis (AS) [1].

The need for early AxSpA detection is based on the importance of a comprehensive control of disease activity. Poorer outcomes associated to diagnostic delay and a greater response to anti-TNF alpha therapy in patients in early stages of the disease supports this argument. Disease activity was the main variable associated to disability in patients with AS [2]. It has also been observed that disease activity contributes longitudinally to spinal radiographic progression in AS, being this effect more noticeable in early stages of the disease ${ }^{3}$.One study demonstrated that patients with a delayed diagnosis of axSpA of over 8 years have a higher disease activity, as well as more radiographic progression and worse functional disability[4]. Alternatively early treatment before the presence of irreversible structural damage might also reduce radiographic progression, as was reported recently in a prospective AS cohort [5]. Finally, it was observed that AxSpA patients with shorter disease duration had a better response to anti-TNF alpha therapy [6].

Unfortunately, in spite of this data, there is an unacceptable delay in AS diagnosis. In 2008 our cohort of 86 patients with AS, the median diagnostic delay was 6.2 years [7]. The main causes which could explain this diagnostic delay are low disease prevalence, poor knowledge of cardinal symptoms by general practitioners, mild symptoms at initial stages of the disease, lack of specific diagnostic tests, slow radiographic progression, and limitation spertaining to conventional diagnostic criteria.

The development of ASAS AxSpA classification criteria in 2009 [8] allowed to partly shortening this diagnostic delay. In a recent reevaluation of 190 patients with AS from our cohort in 2014, applying the new classification criteria the median delay to diagnosis was reduced to 3.5 years (unpublished results).

The cardinal symptom found in patients with AxSpA is 
Inflammatory Back Pain (IBP), present in 70 to $80 \%$ of patients but it is frequently not recognized by non- rheumatologists. Various sets of criteria have defined the presence of IBP, all with similar sensitivity and specificity [9-12]. The frequency of AxSpA in patients with chronic lumbar pain rises from 5.8\% to $33 \%$ in those who met IBP criteria [13-15]. Additionally, clinical, laboratory and imaging findings are relevant to establish early diagnosis of $\mathrm{AS}^{8}$, and various strategies have been proposed to determine their best use [16-23].

The lack of knowledge of disease characteristics by general practitioners, primary care physicians and the general population is another issue that contributes to diagnostic delay. Medical education is one of the main strategies required to increase early diagnosis. This education should be focused on the general population, both with and without symptoms. Regarding medical staff, it should target general practitioners, primary care physicians, as well as other specialists (dermatologists, ophthalmologists, gastroenterologists and orthopedists), particularly reinforcing patient referral strategies to rheumatologists. However, no recommendations for referral strategies to identify these patients early by non rheumatologist colleagues have been developed in our country. Certainly this also may contribute to a delay in diagnosis.

Good medical care depends on both, access to specialists and awareness of a particular condition such as IBP by patients and physicians. Awareness depends on information provided to physicians and the public.

Previous experience showed that AxSpA awareness campaigns allow the possibility to educate the population about disease characteristics, enabling a potential early diagnosis [ 24 25].

For this reason, we designed a National AxSpA "early detection" awareness campaign to detect patients from the general population with IBP. We also evaluate the impact of the different advertising media used during the campaign to also determine its diagnostic value.

\section{Material and Methods}

This pilot study was conducted in two centers, the "Instituto de Rehabilitación Psicofísica" (IREP) in Buenos Aires and the "Hospital Señor del Milagro" in Salta. In November 2012, a fourweek awareness campaign called "MOVETE-YA" ("MOVE-NOW") was presented. Advertisement was promoted through various communication media, such as press, internet (yahoo/terra) and television through a TV spot broadcasted in different open network channels and cable. Informative brochures regarding Low Back Pain (LBP) characteristics were distributed in different areas of the city. Advertisements were focused on raising awareness about AS, and encourage patients suffering from IBP to contact us via e-mail (www.moveteya.com) or telephone call (0-800-moveteya) to a call center available 24/7.

Personnel receiving the emails and telephone operators were adequately trained. They were encouraged applied a predetermined questionnaire (first filter) to detect potential targets.
This questionnaire included socio demographic data (gender, date of birth, age) and Back Pain (BP) characteristics (duration, age at BP onset and previous diagnosis). The main objective of the questionnaire was to determine whether contacts met the inclusion criteria, which were: age $\geq 18$ years old, back pain for a period $\geq 3$ months, age at pain onset $\leq 50$ years, not having a previous AS diagnosis, complying with $4 / 5$ ASAS LBP criteria or $3+$ Calin [10] or Berlin [11] LBP criteria, with the requirement that they did not overlap with any of the 3 points present in the ASAS criteria. If the patient met the inclusion criteria, an appointment was made in one of our participating centers, based on his/her home location.

Patients who fulfill criteria were interviewed and examined by a rheumatologist at a rheumatology center regarding: sociodemographic data, medical history, treatment received, and the presence of IBP. A Physical exam was performed and included: pain assessment (by using a $0-10 \mathrm{~cm}$ Visual Analog Scale (VAS)), presence of morning stiffness, number of swollen and tender joints (based on total 44 joint count) [26], MASES enthesitis score (0-13) [27] and axial mobility scores (BASMI) [28]. Blood samples were collected to determine acute phase reactants (Eritrosedimentation rate and C Reactive Protein) and a poster anterior pelvic X-ray to assess the presence of sacroiliitis was performed. If it was not possible to establish a SpA diagnosis [29] at the first appointment, HLA-B27 and Magnetic Resonance Imaging (MRI) (T1 and STIR sequences) of the sacroiliac joints were performed. Patients were classified according to the ASAS 2009 criteria for AxSpA [8] and the modified New York criteria for AS [30].

The study was approved by the ethics committee of the Instituto de Rehabilitacion Psicofísica and was performed according to the principles of the Declaration of Helsinki.

Statistical analysis: Descriptive statistics was done using frequencies, median and Inter Quartile Range (IQR). Comparison of categorical variables was performed by Chi-squared test or Fisher exact test and continuous variables by Mann Whitney and $\mathrm{T}$ tests, depending on sample distribution.

\section{Results}

In the four-week period of the awareness campaign, a total of 900 patients contacted us: 449 by telephone and 451 by-mails. After initial screening 226 (50.3\%) of the phone calls and 361 $(80.1 \%)$ of the e-mails met initial criteria. (Figure 1)

Analyzing the demographic characteristics of all the initial contacts 727 [ 451 by internet and 276 of 449 by telephone, after excluding wrong and repeated numbers], the median age was 41.5 years (IQR 34-50), with a female predominance421/727 (57.9\%).There were no significant differences with respect to age and sex when comparing contacts by phone or e-mail. Regarding the contacts' origin, 59\% were originally from Buenos Aires, $33.4 \%$ from other provinces, and only $7.7 \%$ from Salta. Regarding the source of contacts, $61.5 \%$ of the recruited patients derived from TV source, 15.1\% from newspapers, 13.8\% from internet (Yahoo/Terra), and 9.6\% from other sources. 
After the first filter (questionnaire), $70 \%$ of the contacts from the call center met the inclusion criteria. In contrast only $7.3 \%$ of the contacts recruited via email met the inclusion criteria. A total of 157 appointments were scheduled, and only 80 (50.9\%) attended. After the rheumatologists clinical evaluations (second filter), only 42 of the 80 patients (52.5\%) definitively met the inclusion criteria. Two of the 42 patients were excluded as they had been previously diagnosed with AS. After carrying out the diagnostic evaluations, 9 patients were classified as AxSpa, 7 of them met the modified New York criteria ${ }^{30}$ for AS and 2 patients met the 2009 ASAS AxSpAcriteria ${ }^{8}$ for $\mathrm{nr}$ AxSpA. Out of the remaining 31 patients: 14 had other diagnosis, mostly lumbar discarthrosis and 17 were lost to follow up (Figure2).

Out of the 9 patients with AxSpA: 66.6\%were female, with a median age of 39 years (IQR 31.5-41.5), median age at LBP onset of 30 years(27.5-37.5) and a median pain duration of 5.33years (IQR 2.3-10.5)..No cases of psoriasis, Inflammatory Bowel Disease (IBD) and/or reactive arthritis were detected.

When we compared socio demographic and clinical variables between those with and without an AxSpA diagnosis, patients with AxSpA were younger without reaching statistical significance (37.6 \pm 6.7 vs. $45.4 \pm 10, p=0.054)$. We found no differences regarding sex or most of IBP characteristics. On the other hand, axial morning stiffness greater than 30 minutes was significantly more frequent in the AxSpA group (77.7\% vs. $37.7 \%, p=0.049$ ), as well as the morning stiffness duration, which was also higher in the AxSpA group $(46.11 \pm 3.77$ minutes vs. $16.21 \pm 11.26$ minutes, $\mathrm{p}=0.046)$. The MASES index was significantly higher in the AxSpA group ( $3.9 \pm 4.6$ vs. $0.5 \pm 1, p=0.049)$. Acute phase reactants: erythrocyte sedimentation rate (ESD) and $\mathrm{C}$ - reactive protein (CRP), were also numerically higher in the AxSpA group (Tables 1 and 2).

\section{Discussion}

This is the first awareness campaign performed in our country to identify patients with IBP from the general population. The frequency of AxSpA in people with IBP from the general population was $22.5 \%$ and AxSpA was detected in $1.3 \%$ of this population unaware of their diagnosis. Television was the main

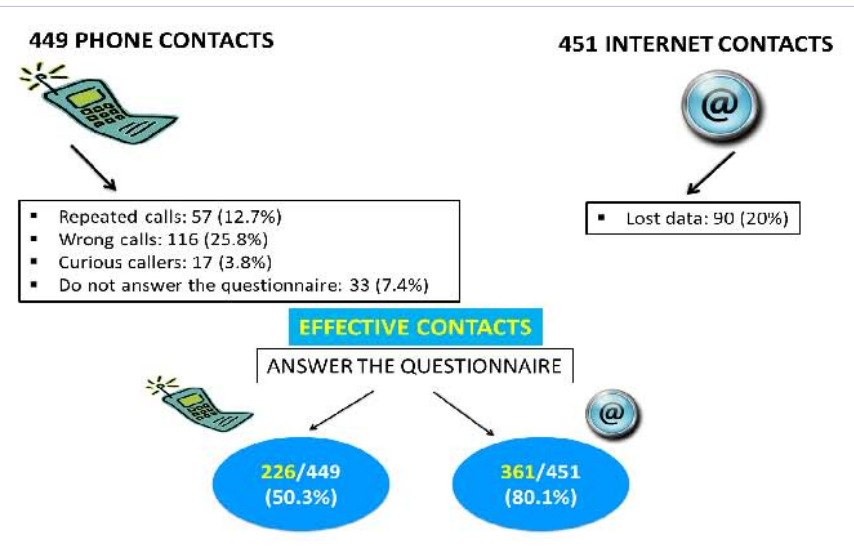

Figure 1: Characteristics of contacts received

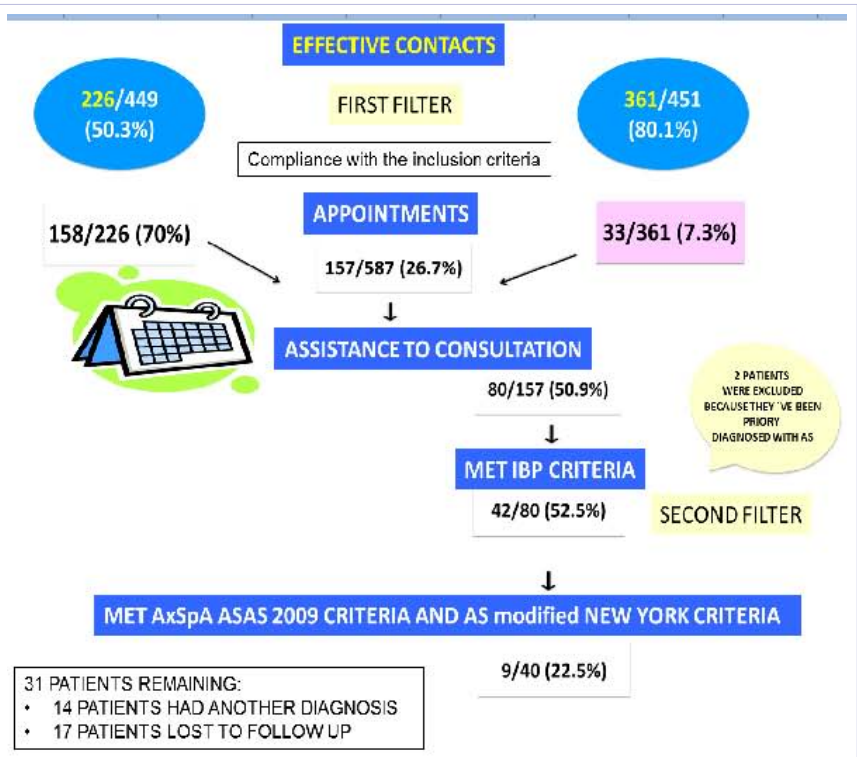

Figure 2: Flow-diagram from conract reception until arrival to definitive diagnosis

Table 1: Comparison of socio demographic and clinical categorical variables amongst patients with and without an $\mathrm{AxSpA}$ diagnosis.

\begin{tabular}{|c|c|c|c|}
\hline \multirow{2}{*}{ VARIABLE } & \multicolumn{2}{|c|}{ AxSpA ASAS 2009CRITERIA } & \multirow[b]{2}{*}{ p } \\
\hline & $\begin{array}{l}\text { NO } \\
n=14(\%)\end{array}$ & $\begin{array}{l}\text { YES } \\
n=9(\%)\end{array}$ & \\
\hline Female & $7(50)$ & $6(66.6)$ & NS \\
\hline Insidious onset pain & $12(85.7)$ & $5(55.5)$ & NS \\
\hline $\begin{array}{l}\text { Pain that improves with } \\
\text { exercise }\end{array}$ & $9(64.2)$ & 8 (88.8) & NS \\
\hline $\begin{array}{l}\text { Pain that doesn't improve } \\
\text { with rest }\end{array}$ & $9(64.2)$ & $9(100)$ & NS \\
\hline Night pain & $6(42.8)$ & $9(100)$ & NS \\
\hline $\begin{array}{l}\text { Pain associated with morning } \\
\text { stiffness }\end{array}$ & $13(92.8)$ & $9(100)$ & NS \\
\hline $\begin{array}{l}\text { Morning stiffness > } 30 \\
\text { minutos }\end{array}$ & $5(35.7)$ & $7(77.7)$ & 0.049 \\
\hline Alternating buttock pain & $9(64.2)$ & $3(33.3)$ & NS \\
\hline Good response to NSAIDs & $3(21.4)$ & $6(66.6)$ & NS \\
\hline Pain prevalence morning & $7(50)$ & $5(55.5)$ & NS \\
\hline Presence of morningstiffness & $13(92.8)$ & $9(100)$ & NS \\
\hline Arthritis/Enthesitis/Dactilitis & $4(28.5)$ & $2(22.2)$ & NS \\
\hline Uveitis & $1(7.1)$ & 0 & NS \\
\hline Radiological sacroiliitis & 0 & 7 (77.7) & NS \\
\hline Family history of SpA & 0 & $2(22.2)$ & NS $(0.06)$ \\
\hline$H L A-B 27$ & 0 & 2/7 (28.6) & NS \\
\hline Treatment with NSAIDs & $12(85.7)$ & $7(77.7)$ & NS \\
\hline
\end{tabular}

recruiting source; the call center was the most effective contact, while internet contacts presented a low yield.

Based on the premise that the probability that a patient with chronic lumbar pain suffers from AxSpA is only 5\% [13-15], we decided to contact those patients presenting IBP. When applying 


\begin{tabular}{|c|c|c|c|}
\hline \multirow[b]{2}{*}{ VARIABLE } & \multicolumn{2}{|c|}{ AxSpA ASAS 2009 CRITERIA } & \multirow[b]{2}{*}{ p } \\
\hline & $\begin{array}{l}\text { NO } \\
n=14 \quad X( \pm)\end{array}$ & $\begin{array}{l}\text { YES } \\
n=9 \times( \pm)\end{array}$ & \\
\hline Age (years) & $45.36( \pm 10)$ & $37.56( \pm 6.7)$ & NS $(0.054)$ \\
\hline $\begin{array}{l}\text { Pain duration } \\
\text { (months) }\end{array}$ & $117( \pm 142.8)$ & $73.44( \pm 52.6)$ & NS \\
\hline Age of pain onset & $35.6( \pm 10.6)$ & $31.8( \pm 7.7)$ & NS \\
\hline ESR mm/h & $9( \pm 7.6)$ & $18.37( \pm 15.9)$ & NS \\
\hline CRPmg\% & $0.65( \pm 1.4)$ & $1.06( \pm 1.3)$ & NS \\
\hline $\begin{array}{l}\text { Morning sitffness } \\
\text { duration (minutes) }\end{array}$ & $16.21( \pm 11.26)$ & $46.11( \pm 3.77)$ & 0.046 \\
\hline Chest expansion $(\mathrm{cm})$ & $7.39( \pm 13.7)$ & $4.05( \pm 1.2)$ & NS \\
\hline $\begin{array}{l}\text { Cervical rotation } \\
\text { (grades) }\end{array}$ & $79.82( \pm 8.15)$ & $72.22( \pm 8.7)$ & NS \\
\hline Pain VAS (cm) & $5.79( \pm 1.7)$ & $6.22( \pm 2.3)$ & NS \\
\hline $\begin{array}{l}\text { Activity by patient } \\
(\mathrm{cm})\end{array}$ & $6.28( \pm 1.9)$ & $6.29( \pm 2.2)$ & NS \\
\hline MASES (0-13) & $0.5( \pm 1)$ & $3.89( \pm 4.6)$ & 0.049 \\
\hline
\end{tabular}

ESR: Eritrosedimentation rate; CRP: C Reactive Protein; VAS: Visual analog scale

the Berlin algorithm to patients with IBP, diagnostic probability of AxSpA rises to $14 \%$. The presence of $\geq 3$ spondyloarthritis features, additionally to the $H L A-B 27$ antigen and SI imaging, increases the probability of having this disease to $80-90 \%$ [16]. Using a cost effective rationale we decided to initially evaluate patients in this study with a SI joint radiograph with the objective of ruling out Ankylosing Spondylitis, subsequently an MRI was performed if radiographic findings were normal or showed low degrees of sacroiliitis.

Given that 70 to $80 \%$ of patients with AxSpA have IBP and that $20-25 \%$ of the patients with AxSpA patients has mechanic lumbar pain, the ASAS group modified the original Berlin algorithm, eliminating IBP as a mandatory entry criterion. In spite that, these modifications have improved sensitivity, they have decreased specificity [17].

Therefore, questioning "Which is the best reference parameter in patients with probable AxSpA?"The answer would depend on a parameter that identifies the largest possible number of patients, but also allows doing so with the least proportion of false negatives ${ }^{31}$. When evaluating the various parameters relevant to an early AxSpA diagnosis, the best LR+/LR- ratio corresponds to the presence of HLA-B27 and sacroiliitis evidenced by MRI, both having a positive $\mathrm{LR}=9$ and a negative $\mathrm{LR}=0.11$, associated to a $90 \%$ sensitivity and specificity. However both are costly studies. In relation to the rest of the parameters evaluated, IBP has a positive $L R=3.1$ and negative $L R=0.33$. For this reason, IBP can be considered the main parameter to be evaluated in patients with probable AxSpA. Other symptoms and disease characteristics have higher positive LR, but due to low prevalence they have less sensitivity [32].

Based on these parameters, single and multicenter studies have developed various reference strategies, with excellent results. They allow for the diagnosis of AxSpA in 35\% of cases, 24$49 \%$ corresponding to non-radiologic AxSpA [18-23]. As already mentioned, we chose to use IBP as the main reference parameter in our study and we found a $22.5 \%$ of AxSpA in people with IBP. This frequency corresponds with the 16 to $33 \%$ reported in previous literature $[15,18,19,21]$. It would be interesting to evaluate whether the no conventional IBP criteria used in this study might have modified the sensitivity and/or specificity in relation to detecting patients with AxSpA. It is important to note that, to date, no AxSpA prevalence studies have been performed in Argentina, although we assume that it might be lower than in other countries with a greater proportion of Anglo-Saxon population.

Nine out of 40 patients with IBP met the AxSpA classification criteria. Fourteen out of 40 (35\%) patients did not meet AxSpA criteria, and IBP could be explained by another cause: $100 \%$ had Degenerative Disc Disease (DDD). Although DDD tends to present with chronic mechanic lumbar pain, Modic I disc diseases may manifest with IBP characteristics [33, 34]. In addition, DDD is most frequently found in older patients, not associated to acute phase reactant changes. These 14 patients from our study were older than the 9 patients with AxSpA, and their acute phase reactant values were numerically lower.

None IBP characteristic have proven to have sufficient sensitivity or specificity in order to be used separately [11]. However, morning stiffness $>30$ minutes long, is the parameter which has the best sensitivity/specificity relationship [11]. Gran $J T$ established that the presence of morning stiffness $>30$ minutes is relevant to AS, with $64 \%$ sensitivity and 58\% specificity [35]. In our study, a relevant finding, when analyzing IBP characteristics separately, was that a morning stiffness duration $>30$ minutes was significantly higher in patients with IBP and AxSpA diagnosis, in contrast to those with IBP not diagnosed with AxSpA. Similarly, the morning stiffness duration was significantly higher in patients with AxSpA.

An important limitation in our study was the $42.5 \%(17 / 40)$ lost to follow up, which was also observed in other disease awareness campaigns [36]. Unfortunately, we could not contact these persons again. This might probably be due to socioeconomic barriers, such as, difficulties inherent to carrying out studies, as well as work or transport limitations impeding appointment attendance, etc.

It is important to consider that TV advertisement provided 
the highest contact yield. This can be explained by the fact that television is an unprecedented, widely spread, means of communication, watched by a large proportion of the population as it meets information and entertainment needs [37]. Due to its audiovisual stimuli, television imposes itself over other forms of communication, penetrating people's homes and daily routines [38].

Regarding recruiting, the call center was the most effective means of contact, in spite of the fact that people in Argentina probably have similar access to phones and internet, and both were cost free. On the other hand, people who visited the web page fulfilled the questionnaire but they later did not attend the appointment. Even more, $70 \%$ of callers coming from the call center met the inclusion criteria, in contrast to only $7.3 \%$ of the Internet contacts. This difference might be explained by a large number of people having only visited the internet site in order to obtain information.

In conclusion, the frequency of AxSpA in persons with IBP in our population was similar to that reported in literature. Television was clearly the best means of communication, and the call center was the most effective way to contact potential patients.

\section{Disclosure Statement}

This study was carried out with a grant from Argentine Society of Rheumatology. The financial resources obtained were used to pay administrative staff and advertising. Physicians involved did not receive any payment.

The authors have declared no other conflict of interest.

\section{References}

1. Citera G. Espondiloartropatías seronegativas. Chapter 31. In Reumatología/Maldonado Cocco JA, Citera G. 1st Edition. 2010

2. Marengo MF, Schneeberger EE, Gagliardi S, Maldonado Cocco JA Citera G. Determinantes de discapacidad funcional en pacientes con espondilitis anquilosante en Argentina. Rev ArgReumatol 2009;20(3):20-25.

3. Ramiro S, van der Heijde D, van Tubergen A, Stolwijk C, Dougados M, van den Bosch F, et al. Higher disease activity leads to more structura damage in the spine in ankylosing spondylitis: 12-year longitudinal data from the OASIS cohort. Ann Rheum Dis. 2014;73(8):1455-1461. DOI: doi: 10.1136/annrheumdis-2014-205178.

4. Seo MR, Baek HL, Yoon HH, Ryu HJ, Choi HJ, Baek HJ, et al. Delayed diagnosis is linked to worse outcomes and unfavourable treatment responses in patients with axial spondyloarthritis. ClinRheumatol. 2015;34(8):1397-1405. DOI: doi: 10.1007/s10067-014-2768-y.

5. Haroon N, Inman RD, Learch TJ, Weisman MH, Lee M, Rahbar $\mathrm{MH}$, et al. The impact of tumor necrosis factor $\alpha$ inhibitors on radiographic progression in ankylosing spondylitis. Arthritis Rheum. 2013;65(10):2645-2654. DOI: doi: 10.1002/art.38070.

6. Rudwaleit M, Listing J, Brandt J, Braun J, Sieper J. Prediction of a major clinical response (BASDAI 50) to tumor necrosis factor $\alpha$ blockers in ankylosing spondylitis. Ann Rheum Dis 2004;63(6):665-670.

7. Collado MV, Marengo MF, Schneeberger EE, Correa MA, Rosemffet M, Citera G, et al. Incapacidad laboral en pacientes con Espondilitis Anquilosante: Puntos de corte y capacidad de discriminación de los principales cuestionarios de autoevaluación. Rev Argent Reumatol 2008;19(4):19.

8. Rudwaleit M, Landewé R, van der Heijde D, Listing J, Brandt J, Braun J, et al. The development of Assessment of SpondyloArthritis international Society classification criteria for axial spondyloarthritis (part I): classification of paper patients by expert opinion including uncertainty appraisal. Ann Rheum Dis. 2009;68(6):770-776. DOI: doi: 10.1136/ard.2009.108217.

9. Dougados M, van der Linden S, Juhlin R, Huitfeldt B, Amor B, Calin A, et al. The European Spondylarthropathy Study Group preliminary criteria for the classification of spondylarthropathy. Arthritis Rheum. 1991;34(10):1218-1227.

10. Calin A, Porta J, Fries JF, Schurman DJ. Clinical history as a screening test for ankylosing spondylitis. JAMA. 1997;237 (24):2613-2614.

11. Rudwaleit M, Metter A, Listing J, Sieper J, Braun J. Inflammatory back pain in ankylosing spondylitis: a reassessment of the clinical history for application as classification and diagnostic criteria. Arthritis Rheum. 2006;54(2):569-578.

12. Sieper J, van der Heijde D, Landewé R, Brandt I, Burgos-Vagas R, Collantes-Estevez E, et al. New criteria for inflammatory back pain in patients with chronic back pain: a real patient exercise by experts from the Assessment of SpondyloArthritis international Society (ASAS). Ann Rheum Dis. 2009;68(6):784-788. DOI: doi: 10.1136/ ard.2008.101501

13. Underwood MR, Dawes P. Inflammatory back pain in primary care. $\mathrm{Br}$ J Rheumatol. 1995;34(11):1074-1077.

14. O'Shea FD, Boyle E, Salonen DC, Ammendolia C, Peterson C, Hsu W, et al. Inflammatory and degenerative sacroiliac joint disease in a primary back pain cohort. Arthritis Care Res (Honoken). 2010;62(4):447-454. DOI: doi: 10.1002/acr.20168.

15.vanOnna M, Gorter S, van Meerendonk A, van Tubergen A. General practitioners' perceptions of their ability to identify and refer patients with suspected axial spondyloarthritis: a qualitative study. J Rheumatol. 2014;41(5):897-901. DOI: doi: 10.3899/jrheum.131293.

16. Rudwaleit M, van der Heijde D, Khan MA, Braun J, Sieper J. How to diagnose axial spondyloarthritis early. Ann Rheum Dis. 2004;63(5):535-543.

17.van den Berg R, de Hooge M, Rudwaleit M, Sieper J, van Gaalen F, Reijnierse $M$, et al. ASAS modification of the Berlin algorithm for dianosing axial spondyloarthritis: results from the SPondyloarthritis Caught Early (SPACE)-cohort and from the Assessment of SpondyloArthritis international Society (ASAS)-cohort. An Rheum Dis. 2013;72(10):1646-1653.

18. Brandt HC, Spiller I, Song IH, Vahldiek JL, Rudwaleit M, Sieper J. Performance of referral recommendations in patients with chronic back pain and suspected axial spondyloarthritis. Ann Rheum Dis. 2007;66(11):1479-1484.

19. Hermann J, Giessauf H, Schaffler G, Ofner P, Graninger W. Early spondyloarthritis: usefulness of clinical screening. Rheumatology (Oxford). 2009;48(7):812-816.

20. Muñoz-Fernández S, de Miguel E, Cobo-Ibáñez T, Carmona L, Steiner M, Descalzo MA, et al. Early spondyloarthritis: results from the pilot registry ESPIDEP. ClinExpRheumatol. 2010;28(4):498-503.

21. Poddubnyy D, Vahldiek J, Spiller I, Buss B, Listing J, Rudwaleit M, et al. Evaluation of 2 screening strategies for early identification of patients with axial spondyloarthritis in primary care. J Rheumatol. 2011;38(11):2452-2460. doi: 10.3899/jrheum.110070. 
22. Braun A, Saracbasi E, Grifka J, Schnitker J, Braun J. Identifying patients with axial spondyloarthritis in primary care: how useful are items indicative of inflammatory back pain? Ann Rheum Dis. 2011;70(10):1782-1787. doi: 10.1136/ard.2011.151167.

23. Sieper J, Srinivasan S, Zamani O. Comparing 2 referral strategies to diagnose axial Spondyloarthritis: RADAR. Ann Rheum Dis. 2011;70(Suppl 3):81.

24. Song IH, Sieper J, Rudwaleit M. Diagnosing early ankylosing spondylitis. CurrRheumatol Rep. 2007;9(5):367-374.

25. Juanola Roura X, Collantes Estévez E, León Vázquez F, Torres Villamor A, García Yébenes MJ, Queiro Silva R, et al. Recomendations for the detection, study and referral of inflammatory low-back pain in Primary Care. ReumatolClin. 2015;11(2):90-98.

26. van der Heijde DM, van der Linden S. Measures of outcome in ankylosing spondylitis and other spondyloarthritides. BaillieresClinRheumatol. 1998;12(4):683-93.

27. Heuft-Dorenbosch L, Spoorenberg A, van Tubergen A, Landewe R, van der Tempel $\mathrm{H}$, Mielants $\mathrm{H}$. Assessment of enthesitis in ankylosing spondylitis. Ann Rheum Dis. 2003; 62(2):127-132.

28. Jenkinson TR, Mallorie PA, Whitelock HC, Kennedy LG, Garrett SL, Calin A. Defining Spinal Mobility in Ankylosing Spondylitis (AS) The Bath AS Metrology Index. J Rheumatol. 1994; 21(9):1694- 1698.

29. Brower A. Disorders of the sacroiliac joint. Radiology. 1978;1:3-26. 30.van der Linden S, Valkenburg HA, Cats A. Evaluation of diagnostic criteria for ankylosing spondylitis. A proposal for modification of the New York criteria. Arthritis Rheum. 1984;27(4):361-368.

31. Manterola DC. Cómo interpretar un artículo sobre pruebas diagnósticas. Rev Med ClinCondes. 2009;20(5):708-717.

32. Poddubnyy D, Rudwaleit M. Early spondyloarthritis. Rheum Dis Clin North Am. 2012;38(2):387-403. doi: 10.1016/j.rdc.2012.04.007.

33. Bailly F, Maigne JY, Genevay S, Marty M, Gandjbakhch F, Rozenberg $S$, et al. Inflammatory pain pattern and pain with lumbar extension associated with Modic 1 changes on MRI: a prospective case-control study of 120 patients. Eur Spine J. 2014;23(3):493-497. doi: 10.1007/ s00586-013-3036-6.

34. Cecchetti S, Pereira B, Roche A, Deschaumes C, Abdi D, Coudeyre E, et al. Efficacy and safety of pamidronate in Modic type 1 changes: study protocol for a prospective randomized controlled clinical trial. Trials. 2014;15:117. doi: 10.1186/1745-6215-15-117.

35. Gran JT. An epidemiological survey of the signs and symptoms of ankylosing spondylitis. ClinRheumatol. 1985;4(2):161-169.

36. Daniel Capurro N, Luigi Gabrielli N, Luz MaríaLetelier S. Intention to treat and follow up are important in assessing validity of a randomized clinical trial. Rev Méd Chile. 2004;132(1):1557-1560.

37. Fernández F. Clase social, exposición a la televisión y percepción de la violencia en la televisión. Estudiossociales. Chile. 1994;12.

38.http://ww11.brinkster.com7telebasura7index.asp 